\title{
Borderline tuberculoid leprosy associated with primary cutaneous histoplasmosis
}

\author{
Hanseníase dimorfa tuberculoide associada à histoplasmose cutânea primária
}

\author{
Carolina Ribas do Nascimento ${ }^{1}$ \\ Antônio Carlos Ceribelli Martelli ${ }^{3}$ \\ Milton Cury Filho5
}

\author{
Ronita Rocelina Carvalhal Silva Soares ${ }^{2}$ \\ Maria Izilda Andrade ${ }^{4}$
}

\begin{abstract}
We describe a case of borderline tuberculoid leprosy associated with primary cutaneous histoplasmosis in a patient who presented at our hospital with skin lesions and joint complaints. Keywords: Granuloma; Histoplasmosis; Leprosy
\end{abstract}

Resumo: Descrevemos um caso de hanseníase dimorfa tuberculoide associada à histoplasmose cutânea primária em um paciente que procurou nosso hospital com lesões dermatológicas e queixas articulares. Palavras-chave: Granuloma; Hanseníase; Histoplasmose

This case concerns a 65 -year-old male patient who suffered pain and lack of mobility in his right wrist a year ago and reported the appearance of erythematous plaques on his body three weeks before presenting at hospital. Examination revealed ulcers on the fingers of his right hand and an erythematousedematous plaque on the dorsum of the right hand, left shoulder and neck (Figures 1 and 2). Biopsy was performed on the dorsum of the hand and neck which showed reactional borderline tuberculoid leprosy (Figure 3). Polychemotherapy and prednisone were started on the assumption that it was "reactional hand." After treatment the joint pains noted at first consultation persisted. We decided to perform a synovial biopsy of the right wrist, with negative culture for bacteria and mycobacteria and positive for Histoplasma capsulatum (Figure 4). After diagnosing

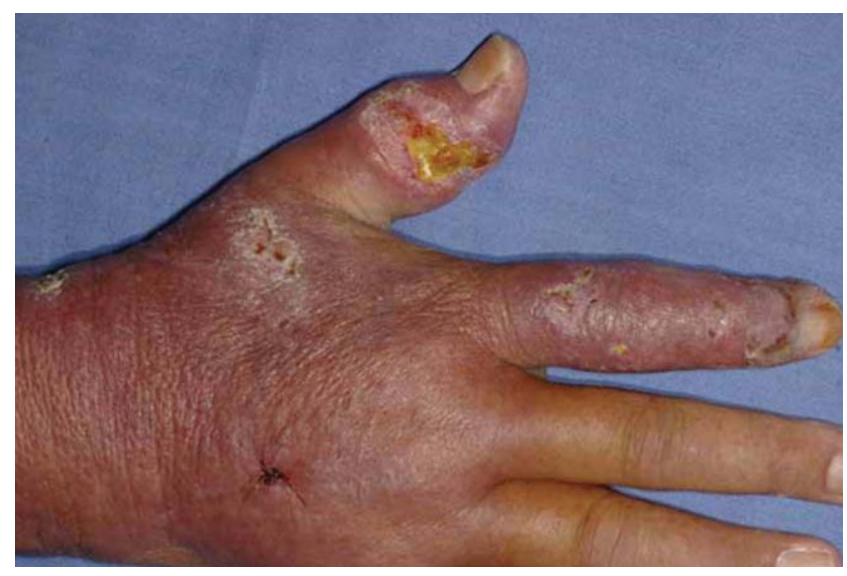

FIGURE 1: Lesions on the fingers and back of right hand. Indurated ulcer with infiltrated edges, fibrinous base and erythematousedematous plaque histoplasmosis, treatment commenced with itraconazole $200 \mathrm{mg}$ daily.

Approved by the Advisory Board and accepted for publication on 08.11.2010

* Study performed at the Lauro de Souza Lima Institute (ILSL), Bauru (SP), Brazil. Conflict of interest: None / Conflito de interesse: Nenhum

Financial funding: None / Suporte financeiro: Nenhum

Dermatologist, studying for Master's Degree in Clinical Medicine/Dermatology at the Federal University of Rio Grande do Sul (UFRGS), Porto Alegre (RS), Brazil. Dermatologist in private practice, Cruzeiro (SP), Brazil.

Assistant Preceptor of Dermatology at the Lauro de Souza Lima Institute (ILSL), Bauru (SP), Brazil.

Biology Assistant in the Medical Mycology Department, Lauro de Souza Lima Institute (ILSL), Bauru (SP), Brazil.

Orthopedic Surgeon at the Lauro de Souza Lima Institute (ILSL), Bauru (SP), Brazil. 


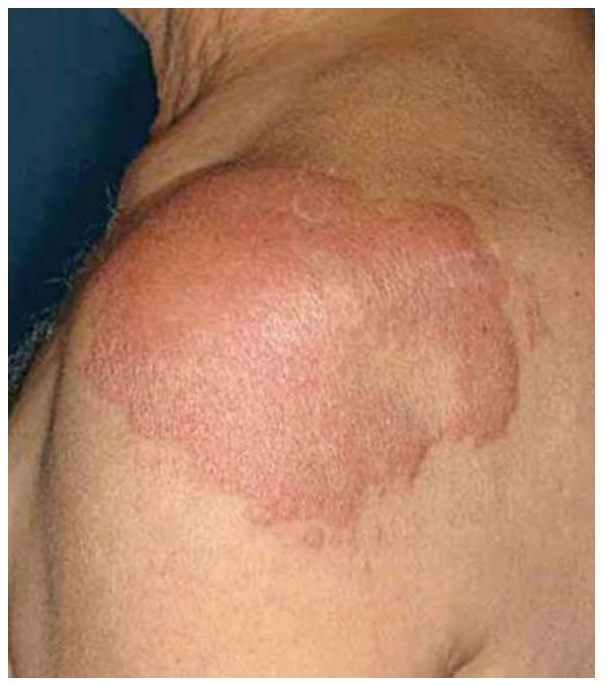

FIGURE 2: Left shoulder lesion. Erythematous plaques with sharply demarcated edges

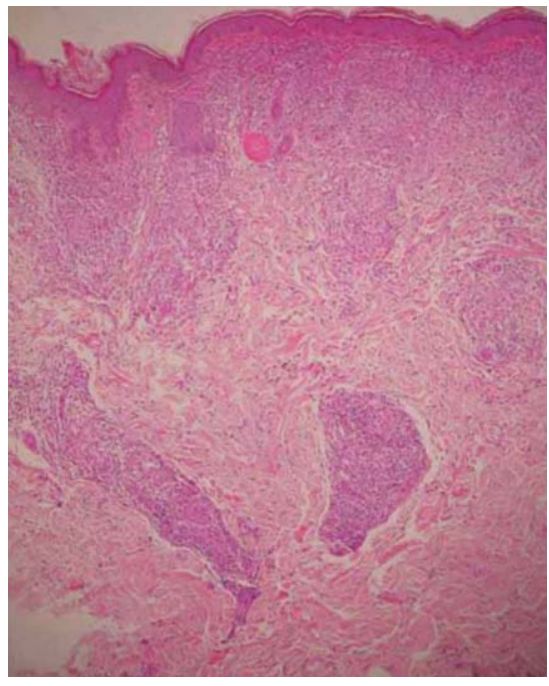

Figure 3:

Anatomopathology of lesion on left shoulder. Reactional tuberculoid pattern in leprosy

\section{REFERENCES}

1. Opromolla DVA. Atualização terapêutica: manual prático de diagnóstico e tratamento. 19 ed. São Paulo: Artes Médica; 1999.

2. Foss, NT. Hanseníase: aspectos clínicos, imunológicos e terapêuticos. An Bras Dermatol. 1999;74:113-9.

3. Silva D, Carvalho T, Brito A. Histoplasmose, relato de um caso. An Bras Dermatol. 1981;56:287-8.

4. Darouiche R0, Cadle RM, Zenon GJ, Weinert MF, Hamill RJ, Lidsky MD. Articular histoplasmosis. J Rheumatol. 1992;19:1991-3.

5. Ward A, Brogden RN, Heel RC, Speight TM, Avery GS. Isotretinoin: A review of its pharmacological properties and therapeutic efficacy in acne and other skin disorders. Drugs. 1984;28:6-37.

6. Plewig G, Nikolowski J, Wolff $\mathrm{HH}$. Action of isotretinoin in acne rosacea and gramnegative folliculitis. J Am Acad Dermatol. 1982;6(Pt 2 Suppl):766-85.

7. Alvarado R, Avendano R, Salfelder K. Primary cutaneous histoplasmosis. Mykosen 1976;19:259-64.

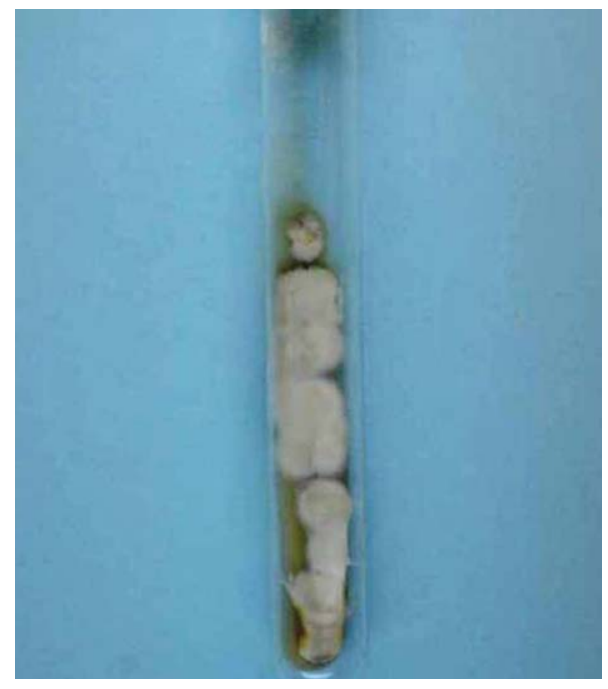

Figure 4: Culture of synovial biopsy specimen of patient's right wrist. $250 \mathrm{C}$-Agar Sabouraud for 30 days. Colony with filamentous appearance, brown to white in color, and cotton-like texture

Leprosy, caused by Mycobacterium leprae, presents a wide spectrum of clinical forms, with stable, opposite poles and unstable manifestations of the disease shifting towards either pole, possibly acquiring the clinical and immunological characteristics of each of the poles. ${ }^{1,2}$

Histoplasmosis, on the other hand, is caused by the dimorphic fungus Histoplasma capsulatum found in soil contaminated by the feces of birds and bats. ${ }^{3-6}$ The disease is endemic in tropical and temperate climates, especially in the Americas.

The case reported shows an association between two granulomatous diseases that has not been reported hitherto in the literature. Assuming that this case was one of reactional borderline leprosy it was to be logically expected that the lesion in the patient's hand would represent one of the symptoms generally found in such leprosy cases.

\author{
MAILING ADDRESS / ENDEREÇO PARA CORRESPONDÊNCIA : \\ Carolina Ribas do Nascimento \\ Rodovia Comandante João Ribeiro de Barros KM \\ 225/226 \\ CEP: 17034-971 Bauru - SP, Brazil \\ E-mail: dra.carolribas@gmail.com
}

How to cite this article/Como citar este artigo: Nascimento CR, Soares RRCS, Martelli ACM, Andrade MI, Cury Filho M. Borderline tuberculoid leprosy associated with primary cutaneous histoplasmosis. An Bras Dermatol. 2012;87(1):146-7. 